\title{
Salana multivorans gen. nov., sp. nov., a novel actinobacterium isolated from an anaerobic bioreactor and capable of selenate reduction
}

\footnotetext{
1 Institut für Mikrobiologie und Hygiene, Universitätsklinikum Charité, Humboldt Universität zu Berlin, Dorotheenstr. 96, D-10117 Berlin, Germany

2 Institut für Biologie, Humboldt Universität zu Berlin, Chausseestr. 117, D-10115 Berlin, Germany

3 Hahn Meitner Institut Berlin $\mathrm{GmbH}$, Abteilung NG, Glienicker Str. 100, D-14109 Berlin, Germany

4 DSMZ-Deutsche Sammlung von Mikroorganismen und Zellkulturen $\mathrm{GmbH}$, Mascheroder Weg 1b, D-38124 Braunschweig, Germany

5 GBF-Gesellschaft für Biotechnologische Forschung $\mathrm{GmbH}$, Mascheroder Weg 1, D-38124 Braunschweig, Germany
}

\author{
Friedrich von Wintzingerode, ${ }^{1}$ Ulf B. Göbel, ${ }^{1}$ Roman A. Siddiqui, ${ }^{2}$ \\ Ullrich Rösick, ${ }^{3}$ Peter Schumann, ${ }^{4}$ Anja Frühling, ${ }^{4}$ Manfred Rohde, ${ }^{5}$ \\ Rüdiger Pukall ${ }^{4}$ and Erko Stackebrandt ${ }^{4}$
}

Author for correspondence: Ulf B. Göbel. Tel: +49 30 20934715. Fax: +49 3020934703. e-mail: ulf.goebel@charite.de
Keywords: Actinobacteria, Micrococcineae, $16 \mathrm{~S}$ rDNA, anaerobic selenate reduction, trichlorobenzene-dechlorinating bioreactor

\section{INTRODUCTION}

Chlorinated organic compounds are widespread environmental pollutants due to their extensive application and chemical stability. Microbial reductive dehalogenation is a key process for the degradation of these compounds in contaminated anaerobic environments (Holliger et al., 1997). In the past, several anaerobic, reductively dechlorinating microorganisms have been isolated in pure culture (for a review, see El Fantroussi et al., 1998). Recent cultureindependent 16S rDNA-based studies of mixed cultures dechlorinating chloro-organic compounds revealed high bacterial diversity. However, the population structure suggested that reductive dechlorination might depend on a specific microbial community comprising both dechlorinating and non-dechlorinating micro-organisms (Schlötelburg et al., 2000; von Wintzingerode et al., 1999, 2000). Based on phylogenetic analysis of an anaerobic trichlorobenzenedechlorinating microbial consortium, cultivation

The EMBL accession number for the 16S rDNA sequence of Salana multivorans Se- $3111^{\top}$ is AJ400627. efforts were made to obtain $16 \mathrm{~S}$ rDNA phylotypes (SJA phylotypes) as cellular isolates (von Wintzingerode et al., 1999; von Wintzingerode, 1999). By using enrichment conditions that favoured growth of the phylogenetically closest cultivated neighbours, the Pseudomonas aeruginosa-like phylotype SJA-64 was successfully isolated (von Wintzingerode, 1999). Here, we describe a group of strains isolated in an attempt to obtain phylotype SJA-186 (von Wintzingerode et al., 1999) in pure culture. Since phylotype SJA-186 was closely related to Thauera selenatis, a selenate-respiring bacterium (Macy et al., 1993), enrichment conditions favouring anaerobic selenate respiration were chosen. From these enrichment cultures, several as yet unclassified bacterial strains capable of anaerobic selenate reduction were isolated (von Wintzingerode, 1999). Comparative 16S rDNA sequence analysis revealed three of these strains to be members of the suborder Micrococcineae within the class Actinobacteria (Stackebrandt et al., 1997), not related to any currently described genus of the Micrococcineae. This distinct phylogenetic position was supported by chemotaxonomic and physiological characteristics. Based on our results, we conclude that 


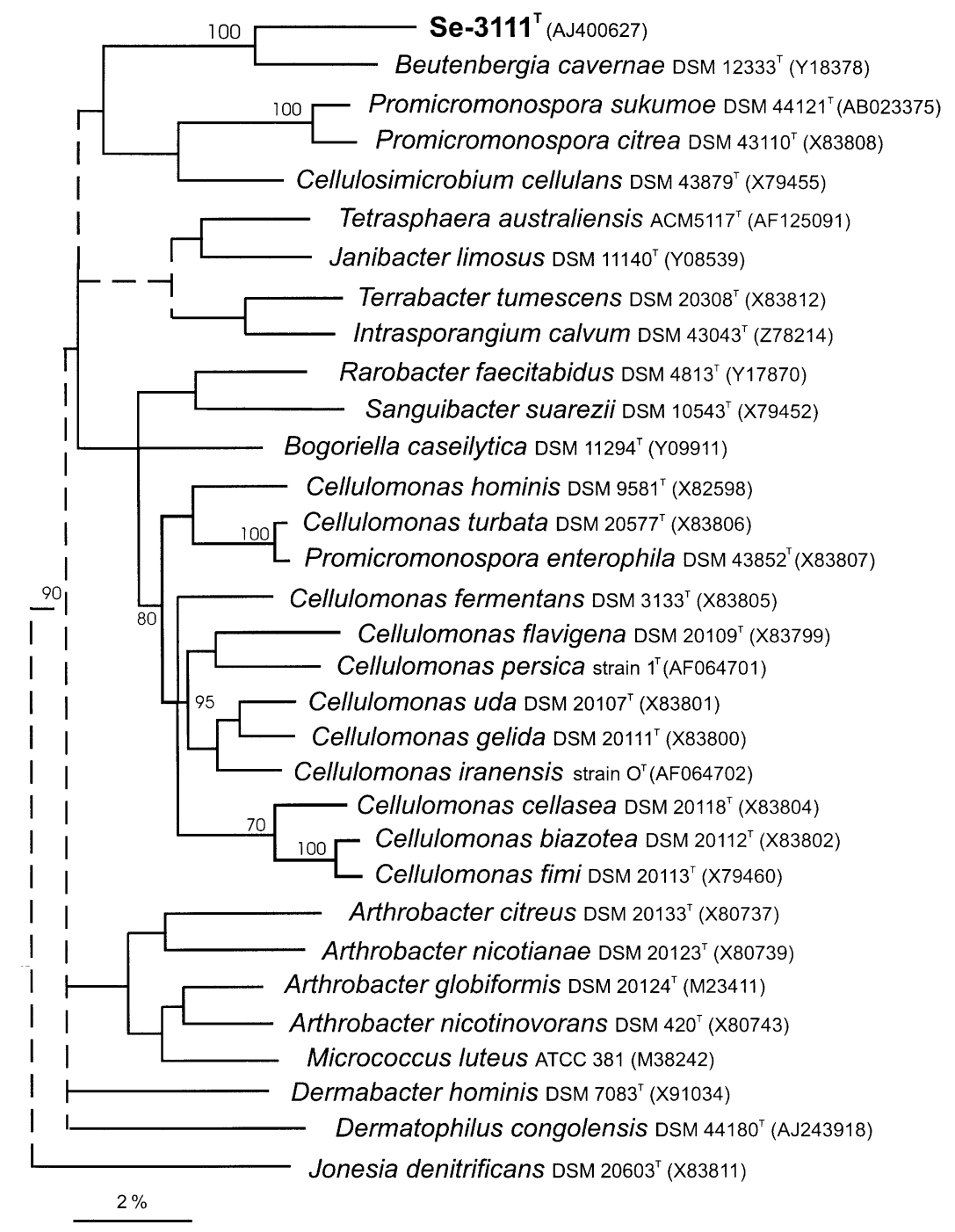

Fig. 1. $16 \mathrm{~S}$ rDNA-based phylogenetic dendrogram constructed from distance-matrix analysis showing the phylogenetic position of strain Se-3111 ${ }^{\top}$ within members of the suborder Micrococcineae. Dashed lines mark branching points that changed with varying treeing methods. Numbers at relevant branching point refer to bootstrap values (100 trees resampled). Bar, 2\% sequence divergence.

all three strains should be classified in a new genus and species, for which we propose the name Salana multivorans gen. nov., sp. nov. The type strain is Se$3111^{\mathrm{T}}\left(=\mathrm{DSM} 13521^{\mathrm{T}}=\right.$ NRRL B-24118 $\left.{ }^{\mathrm{T}}\right)$.

\section{METHODS}

Material, media and culture conditions. Samples were taken from a fluidized bed reactor inoculated with an anaerobic, trichlorobenzene-dechlorinating consortium enriched from river sediment (Selent, 1999). Sediment samples were taken from the River Saale approximately $300 \mathrm{~m}$ upstream of Schöps, near Jena, Germany, in a previous study (Nowak, 1994). Within the fluidized bed reactor, the dechlorinating consortium was immobilized on $1 \mathrm{~cm}^{3}$ polyurethane foam cubes. For enrichment of anaerobic, selenate-reducing bacteria, foam cubes were removed from the bioreactor with sterile forceps and transferred to reduced RAMM medium (Shelton \& Tiedje, 1984). After $7 \mathrm{~d}$ of incubation at $30^{\circ} \mathrm{C}$ under anaerobic conditions (GasPak anaerobic jars, Anaerogen jars), enrichment cultures were set up by transferring one foam cube each to Erlenmeyer flasks containing $50 \mathrm{ml}$ Se medium (Macy et al., 1989) containing $\left(1^{-1}\right): 2 \cdot 2 \mathrm{~g}$ $\mathrm{NaCl}, 0.3 \mathrm{~g} \mathrm{KCl}, 0.3 \mathrm{~g} \quad \mathrm{NH}_{4} \mathrm{Cl}, 0.2 \mathrm{~g} \mathrm{KH_{2 }} \mathrm{PO}_{4}, 0.15 \mathrm{~g}$ $\mathrm{CaCl}_{2} \cdot 2 \mathrm{H}_{2} \mathrm{O}, 0.4 \mathrm{~g} \mathrm{MgCl}_{2} \cdot 6 \mathrm{H}_{2} \mathrm{O}, 0.6 \mathrm{~g} \mathrm{NaHCO}, 3.78 \mathrm{~g}$
$\mathrm{Na}_{2} \mathrm{SeO}_{4}, 3.78 \mathrm{~g}$ potassium acetate, $10 \mathrm{ml}$ trace-metal solution SL8, $10 \mathrm{ml}$ vitamin solution and $800 \mu \mathrm{l}$ methanol. After $5 \mathrm{~d}$ of anaerobic incubation in anaerobic jars (Mart) $\left(\mathrm{CO}_{2} / \mathrm{N}_{2} / \mathrm{H}_{2}\right.$ atmosphere $)$, a red precipitate was visible, which served as an inoculum for subcultures in modified Se medium (Se medium supplemented with $1.2 \mathrm{~g} \mathrm{NaCl}^{-1}$ and also $1-4 \mathrm{~g}$ yeast extract $1^{-1}, 0.3 \mathrm{~g} \mathrm{Na}_{2} \mathrm{SO}_{4} \mathrm{1}^{-1}$ and $2.02 \mathrm{~g}$ $\left.\mathrm{KNO}_{3} 1^{-1}\right)$. Pure cultures were obtained by repeated streaking on plates that contained the medium described above solidified with $15 \mathrm{~g}$ agar $1^{-1}$. Cells were stored at $-70{ }^{\circ} \mathrm{C}$ in liquid growth medium supplemented with 30 $50 \%(\mathrm{v} / \mathrm{v})$ glycerol.

Electron microscopy. Bacteria grown in liquid culture were adsorbed onto poly-L-lysine-coated cover slips $(12 \mathrm{~mm}$ diameter), fixed with $3 \%$ glutaraldehyde for $15 \mathrm{~min}$ at room temperature and washed three times with TE buffer $(20 \mathrm{mM}$ Tris/HCl, 1 mM EDTA, pH 7·0). Samples were dehydrated with a graded series of acetone $(10,30,50,70,90,100 \%)$, critical-point dried with $\mathrm{CO}_{2}$ (Balzers, CPD030) and sputtercoated with a gold film (approximately $10 \mathrm{~nm}$ thick, Bal-Tec SCD040). Samples were examined in a Zeiss field-emission scanning electron microscope Gemini DSM 982 at an acceleration voltage of $5 \mathrm{kV}$ using the In-lens and EverhardtThomley SE detector in a 50:50 ratio. Pictures were stored digitally and processed using Adobe Photoshop 5·5. 


\section{Table 1. Differential characteristics of strain Se-3111 ${ }^{\top}$ and selected taxa with murein type $A 4 \alpha$ or $A 4 \beta$ and $M K-8\left(H_{4}\right)$}

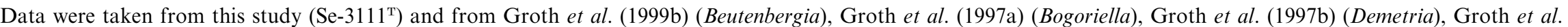
(1999a) (Ornithinicoccus) and Groth et al. (2001) (Ornithinimicrobium). Abbreviations: L-Orn, L-ornithine; DPG, diphosphatidylglycerol; PE, phosphatidylethanolamine; PG, phosphatidylglycerol; PI, phosphatidylinositol; Pser, phosphatidylserine; PL(s), unknown phospholipid(s); GL(s), unknown glycolipid(s); A, anteiso methyl-branched; $\mathrm{I}$, iso methyl-branched; S, straight-chain saturated; U, monounsaturated.

\begin{tabular}{|c|c|c|c|c|c|c|}
\hline Characteristic & Strain Se-3111 ${ }^{\mathrm{T}}$ & Beutenbergia & Bogoriella & Demetria & Ornithinicoccus & Ornithinimicrobium \\
\hline Cell morphology & $\begin{array}{l}\text { Rod, coccoid, } \\
\text { club-like }\end{array}$ & $\begin{array}{c}\text { Rod/coccus cycle, } \\
\text { non-sporulating }\end{array}$ & $\begin{array}{c}\text { Irregular, } \\
\text { rod, coccoid, } \\
\text { non-sporulating }\end{array}$ & $\begin{array}{c}\text { Coccoid, } \\
\text { short rods, } \\
\text { non-sporulating }\end{array}$ & Cocci & $\begin{array}{c}\text { Irregular } \\
\text { rods and cocci }\end{array}$ \\
\hline $\mathrm{G}+\mathrm{C}$ content $(\mathrm{mol} \%)$ & 75 & 71 & 70 & 66 & 72 & 70 \\
\hline Peptidoglycan type* & L-Ser/L-Orn-L-Glu & L-Ala/L-Lys-L-Glu & $\begin{array}{l}\text { L-Ala/L-Lys- } \\
(\text { L-Ala })_{2}-\text { L-Glu }\end{array}$ & $\begin{array}{l}\text { L-Ala/L-Lys- } \\
\text { L-Ser-D-Asp }\end{array}$ & $\begin{array}{l}\text { L-Ala/L-Orn- } \\
\text { Gly }_{(1-2)}-\text { D-Glu }\end{array}$ & $\begin{array}{c}\text { L-Ala/L-Orn- } \\
\text { L-Ala-Gly-D-Asp }\end{array}$ \\
\hline Murein type & $\mathrm{A} 4 \beta$ & $\mathrm{A} 4 \alpha$ & $\mathrm{A} 4 \alpha$ & $\mathrm{A} 4 \alpha$ & $\mathrm{A} 4 \beta$ & $\mathrm{A} 4 \beta$ \\
\hline Polar lipids & PG, DPG, PLs & PI, DPG, 3 PLs & PG, DPG, PI, 1 PL & PI, PG, DPG, PE, 2 PLs & PI, PG, DPG, Pser, PLs & PI, PG, DPG, PLs, GLs \\
\hline Fatty acid types & $\mathrm{S}, \mathrm{A}, \mathrm{I}$ & $\mathrm{S}, \mathrm{A}, \mathrm{I}$ & A, I & $\mathrm{S}, \mathrm{U}, \mathrm{A}, \mathrm{I}$ & $\mathrm{S}, \mathrm{A}, \mathrm{I}$ & $\mathrm{S}, \mathrm{A}, \mathrm{I}$ \\
\hline
\end{tabular}

* Amino acid at position 1 of peptide subunit/interpeptide bridge. 
Determination of anaerobic selenate reduction. Strains were grown anaerobically in $4 \mathrm{ml}$ cultures of basic medium (Se medium without methanol, supplemented with $4 \mathrm{~g}$ gluconate, $1.2 \mathrm{~g} \mathrm{NaCl}, 0.3 \mathrm{~g} \mathrm{Na}_{2} \mathrm{SO}_{4}$ and $0.1 \mathrm{~g}$ yeast extract ${ }^{-1}$ ) at $30{ }^{\circ} \mathrm{C}$. For the determination of elemental selenium, cells were collected by centrifugation $(2500 \mathrm{~g}, 15 \mathrm{~min})$ in FEP vials (tetrafluorethylene/perfluorethylene) and washed once with $2 \mathrm{ml}$ PBS to remove soluble selenium salts. The resulting cell pellets were lysed in $1.0 \mathrm{ml}$ Suprapure nitric acid (Merck) by pressurized digestion $\left(2 \mathrm{~h}\right.$ at $110^{\circ} \mathrm{C}$ and $3 \mathrm{~h}$ at $\left.160{ }^{\circ} \mathrm{C}\right)$. Selenium was determined by electrothermal atomic absorption spectrometry (ETAAS) using a Perkin-Elmer 5100 spectrometer.

Phenotypic tests. Cells were grown aerobically at $30{ }^{\circ} \mathrm{C}$ for $48 \mathrm{~h}$ on Columbia blood agar (Oxoid) containing $5 \%(\mathrm{v} / \mathrm{v})$ defibrinated sheep blood. Motility was tested by both phasecontrast microscopy of overnight cultures grown in DSM 736 liquid medium at $30{ }^{\circ} \mathrm{C}$ and by examining colony morphology on Luria-Bertani (LB) swarming agar $(0.8 \mathrm{~g}$ $\mathrm{NaCl}^{-1}, 0 \cdot 3 \%$ agar). API $50 \mathrm{CH}$, API $20 \mathrm{~A}$ and API ZYM tests (bioMérieux) were used for biochemical characterization. For inoculation of API 50CH, a modified basic medium was used (Se medium without selenate, methanol, $\mathrm{KNO}_{3}$ and acetate, supplemented with $1 \mathrm{~g}$ yeast extract and $0 \cdot 18 \mathrm{~g}$ phenol red $\mathrm{l}^{-1}$ ). All tests were incubated at $30^{\circ} \mathrm{C}$. At least two replicates of each test were performed. For determination of the optimal $\mathrm{pH}$ for growth, cells were grown on LB agar at $\mathrm{pH} 6,7 \cdot 5,9$ and 11 . For determination of optimal temperature, cells were grown on LB agar at $\mathrm{pH}$ 7.5 at room temperature (approx. $23{ }^{\circ} \mathrm{C}$ ), 30, 37 and $40{ }^{\circ} \mathrm{C}$.

Chemotaxonomy. Peptidoglycan structure was elucidated by analyses of cell wall hydrolysates employing the following methods: qualitative analysis of amino acids and peptides by two-dimensional TLC on cellulose plates using solvent systems described previously (Schleifer \& Kandler, 1972), quantitative amino acid analysis by $\mathrm{GC}$ and $\mathrm{GC} / \mathrm{MS}$ (MacKenzie, 1987; Groth et al., 1996), dinitrophenylation of N-terminal amino acids of the interpeptide bridge (Schleifer, 1985) and enantiomeric amino acid analysis using a chiral GC column (Groth et al., 1997b). Menaquinones were analysed by HPLC as described previously (Groth et al., 1996). GC determination of cellular fatty acid profiles was performed as published previously (Schumann et al., 1997). Polar lipids extracted by the method of Minnikin et al. (1979) were identified by two-dimensional TLC on silica gel and spraying with specific reagents (Collins \& Jones, 1980).

DNA base composition. DNA was isolated using a French pressure cell and was purified by chromatography on hydroxyapatite as described by Cashion et al. (1977). The $\mathrm{G}+\mathrm{C}$ content was determined by reverse-phase HPLC of nucleosides according to Mesbah et al. (1989).

$16 \mathrm{~S}$ rDNA sequencing and phylogenetic analyses. The nearly complete $16 \mathrm{~S}$ rRNA genes of all three strains were amplified by PCR from cell lysates using primers TPU1 (5'-AGAGTTTGATCMTGGCTCAG-3', Escherichia coli positions 8-27) and RTU8 (5'-AAGGAGGTGATCCANCCRCA$3^{\prime}$, E. coli positions $1522-1541$ ) and cloned by TA cloning as recommended by the manufacturer (Invitrogen). Inserts were reamplified and sequenced as described previously (von Wintzingerode et al., 2000). Sequencing reactions were analysed on an automated LICOR DNA-4000L sequencer (MWG-BIOTECH). Phylogenetic analyses were performed by using the ARB software package (Ludwig \& Strunk, 1997) and by distance-matrix analyses based upon phylogenetic distance values that compensate for multiple substitutions at any given site in the sequence (Jukes \& Cantor, 1969), using the algorithm of De Soete (1983), the neighbour-joining method (Saitou \& Nei, 1987) and the maximum-likelihood method DNAML contained in the PHYLIP package (Felsenstein, 1993). Bootstrap values were determined using the method of Felsenstein (1985) with 100 bootstrap resamplings. All analyses were done on a SUN SparcII workstation.

Ribotyping. Automated ribotyping was carried out with the RiboPrinter microbial characterization system (Qualicon; DuPont). Sample preparation and analysis was performed according the manufacturer's instructions, using $P v u I I$ to generate restriction fragments. The band patterns were compared by using the BioNumerics software (Applied Maths). Clustering was performed by the unweighted pair group method with arithmetic averages (UPGMA) based on Pearson's correlation coefficient, using an optimization coefficient of $1 \cdot 2 \%$.

\section{RESULTS AND DISCUSSION}

\section{Phylogenetic analysis}

Nearly complete 16S rDNA sequences (1447-1517 nucleotides) of strains Se-3111 ${ }^{\mathrm{T}}$, Se-13111 and Se1311A were compared and found to be identical. The sequence of strain Se-3111 $1^{\mathrm{T}}(1447$ nucleotides between positions 35 and 1499, E. coli numbering) was most similar to those of members of the suborder Micrococcineae, order Actinomycetales, class Actinobacteria ( $>91 \%$ similarity) and it shares all but one signature nucleotide ( $\mathrm{G}$ residue at position 98 ) indicated by Stackebrandt et al. (1997) with members of this suborder. The highest similarity value was found to the sequence of Beutenbergia cavernae ( $95 \%$ ), while similarity to other members was significantly lower, ranging between 91 and $93 \%$. In the $16 \mathrm{~S}$ rDNA dendrograms generated by the distance-matrix algorithms of De Soete (1983) and Saitou \& Nei (1987) and by maximum-likelihood analyses (Felsenstein, 1993), the branching point of strain Se-311 $1^{\mathrm{T}}$ and B. cavernae was stable (Fig. 1). This branching was supported by a high bootstrap value. The differences between the

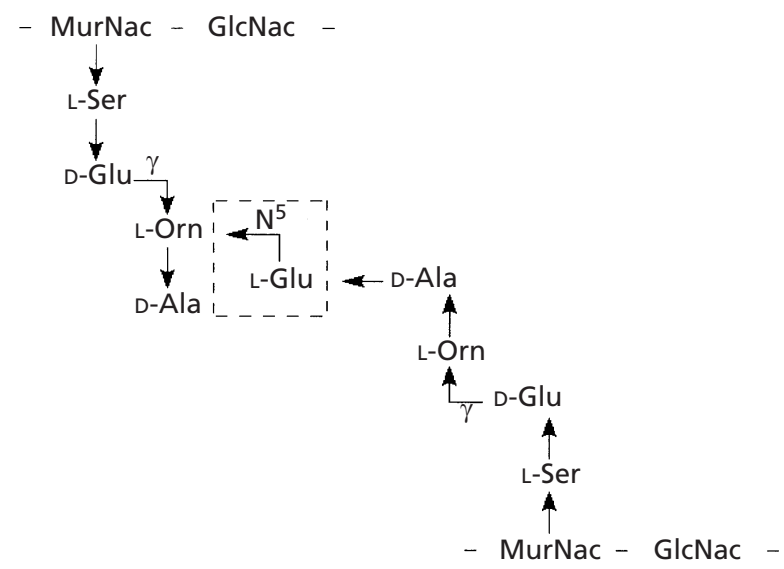

Fig. 2. Fragment of the peptidoglycan structure of strain Se$3111^{\top}$, showing L-serine at position 1 of the peptide subunit and L-glutamic acid as the interpeptide bridge (dashed frame). MurNac, $\mathrm{N}$-Acetylmuramic acid; GlcNac, $\mathrm{N}$-acetylglucosamine. 


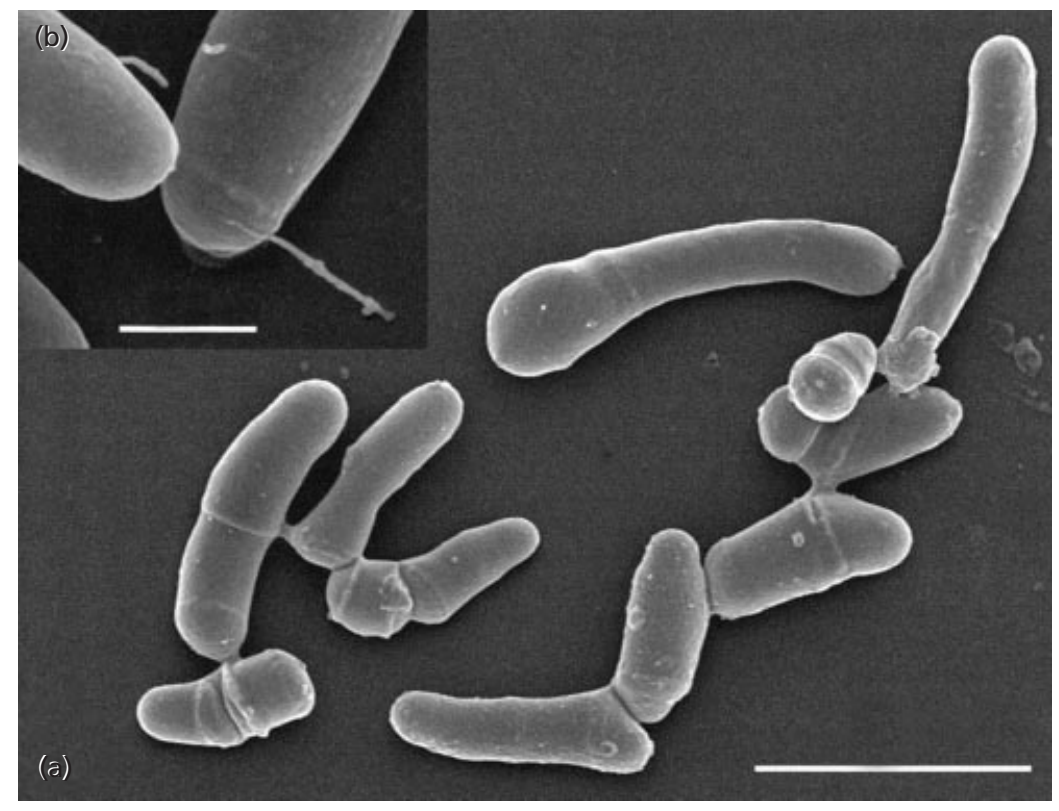

Fig. 3. Scanning electron micrographs of cells of strain Se-3111 ${ }^{\top}$. (a) Rod-shaped, coccoid and club-like cell morphotypes of strain Se-3111 ${ }^{\top}$. Bar, $2 \mu \mathrm{m}$. (b) Stalk-like elements located at the cell pole, Bar, $0.2 \mu \mathrm{m}$.

dendrograms generated by distance-matrix and maximum-likelihood analyses were seen in the order in which the lower-branching lineages emerged, without, however, affecting the genus affiliation of these lineages. The only example is the disconnection of Janibacter and Tetrasphaera from the cluster containing Intrasporangium, Terracoccus and Terrabacter (I. Groth, P. Schumann, B. Schuetze, K. Augsten \& E. Stackebrandt, unpublished results) in the maximumlikelihood analysis.

\section{Cell wall analysis}

The peptidoglycan of strains Se- $3111^{\mathrm{T}}$, Se-1311A and Se-13111 contained Ala, Ser, Orn and Glu in a molar ratio of $0 \cdot 6: 0 \cdot 9: 1 \cdot 0: 1 \cdot 5$ (strain $\mathrm{Se}-3111^{\mathrm{T}}$ ). Dinitrophenylated Glu was detected in hydrolysates of cell wall preparations treated with 1-fluoro-2,4-dinitrobenzene. Enantiomeric analysis of cell wall amino acids resulted in detection of D-Ala, L-Ser, L-Orn, DGlu and L-Glu (molar ratio 1·1:1·0). L-Ala was absent. From these results and from the occurrence of the peptides D-Ala $\rightarrow$ L-Glu and L-Ser $\rightarrow$ D-Glu and the absence of L-Orn $\leftarrow$ L-Ser in the two-dimensional TLC peptide patterns (data not shown), it was concluded that strains Se-3111 ${ }^{\mathrm{T}}$, Se-1311A and Se-13111 are characterized by a not previously observed peptidoglycan structure with an L-Orn $<\mathrm{L}$-Glu interpeptide bridge and an L-Ser residue at position 1 of the peptide subunit (Table 1, Fig. 2). The occurrence of L-Ser at position 1 of the peptide subunit is unique among the genera of the suborder Micrococcineae and differentiates strains Se-3111 ${ }^{\mathrm{T}}$, Se-1311A and Se-13111 from all phylogenetic neighbours. B. cavernae, showing the highest 16S rDNA similarity, differs additionally in its peptidoglycan type $\mathrm{A} 4 \alpha$, based on lysine, from the novel isolates, which show ornithine as the characteristic diamino acid (peptidoglycan type A4 $\beta$ ).

\section{Lipid analysis}

The polar lipid patterns of strains Se-3111 ${ }^{\mathrm{T}}$, Se1311A and Se-13111 contained phosphatidylglycerol, diphosphatidylglycerol and several unidentified phospholipids in minor amounts. Amino-functional lipids and glycolipids were not found. The cellular fatty acid profiles of the three strains were similar. Strain Se$3111^{\mathrm{T}}$ contained the following components: $23 \cdot 0 \%$ tetradecanoic acid, $1.0 \%$ pentadecanoic acid, $17.0 \%$ hexadecanoic acid, 2.9\% 12-methyl tridecanoic acid, $2 \cdot 3 \%$ 14-methyl pentadecanoic acid, 50.4\% 12-methyl tetradecanoic acid, 1.0\% 13-methyl tetradecanoic acid and $1.5 \%$ 14-methyl hexadecanoic acid. The major menaquinone was MK-8 $\left(\mathrm{H}_{4}\right)$. MK-6 $\left(\mathrm{H}_{4}\right)$, MK-7 $\left(\mathrm{H}_{4}\right)$ and MK-8( $\left.\mathrm{H}_{2}\right)$ occurred as minor components (Table 1). The novel isolates can be differentiated from their closest phylogenetic neighbour, B. cavernae, by the absence of phosphatidylinositol, by higher contents of the cellular fatty acids tetradecanoic and hexadecanoic acids and by a remarkably lower content of 13-methyl tetradecanoic acid.

\section{DNA base composition}

Strain Se-3111 ${ }^{\mathrm{T}}$ had a DNA G $+\mathrm{C}$ content of 75 $\mathrm{mol} \%$.

\section{Cultural and morphological characteristics}

Using culture conditions that favoured anaerobic, respiratory selenate reduction, we isolated strains Se$3111^{\mathrm{T}}$, Se-13111 and Se-1311A from a dechlorinating microbial consortium. Cells of these strains formed slightly red-coloured colonies (diameter $0.3-0.6 \mathrm{~mm}$ ) when grown under anaerobic conditions for $14 \mathrm{~d}$ on selenate-containing medium. When grown aerobically 
Table 2. Differences in physiological characteristics of the novel isolates and $B$. cavernae

All tests were performed in duplicate. Abbreviations: + , positive; $+/-$, weak positive reaction; -, negative. B. cavernae was described as an aerobic organism (Groth et al., 1999b).

\begin{tabular}{|c|c|c|c|c|}
\hline Characteristic & $\mathrm{Se}-3111^{\mathrm{T}}$ & Se-13111 & Se-1311A & B. cavernae \\
\hline \multicolumn{5}{|c|}{ Anaerobic formation of acid from (API 20A): } \\
\hline Glucose & + & + & + & $+/-$ \\
\hline Mannitol & + & + & + & - \\
\hline Lactose & + & + & + & - \\
\hline Sucrose & + & + & + & $+/-$ \\
\hline Maltose & + & + & + & $+/-$ \\
\hline Xylose & + & + & + & $+/-$ \\
\hline Salicin & + & + & + & $+/-$ \\
\hline Arabinose & + & + & + & $+/-$ \\
\hline Glycerol & + & + & + & - \\
\hline Cellobiose & + & + & + & - \\
\hline Mannose & + & + & + & $+/-$ \\
\hline Melezitose & + & + & + & - \\
\hline Raffinose & + & + & + & - \\
\hline Sorbitol & + & + & + & - \\
\hline Rhamnose & + & + & + & - \\
\hline Trehalose & + & + & + & - \\
\hline \multicolumn{5}{|c|}{ Aerobic enzyme activity of (API ZYM): } \\
\hline Lipase $\left(\mathrm{C}_{14}\right)$ & $+/-$ & - & - & - \\
\hline Valine arylamidase & + & + & + & - \\
\hline Trypsin & - & $+/-$ & - & - \\
\hline$\beta$-Glucosidase & + & + & + & - \\
\hline$\alpha$-Fucosidase & - & - & - & + \\
\hline \multicolumn{5}{|c|}{ Aerobic formation of acid from (API $50 \mathrm{CH})$ : } \\
\hline Glycerol & + & - & + & - \\
\hline D-Arabinose & + & - & + & + \\
\hline Ribose & + & - & $+/-$ & + \\
\hline D-Xylose & + & $+/-$ & + & + \\
\hline Methyl $\beta$-D-xyloside & + & + & - & - \\
\hline Methyl $\alpha$-D-mannoside & + & + & + & - \\
\hline Amygdalin & + & + & - & - \\
\hline Arbutin & + & + & + & - \\
\hline Salicin & + & + & + & - \\
\hline Cellobiose & + & + & + & - \\
\hline Lactose & + & + & + & - \\
\hline Inulin & + & + & - & - \\
\hline Melezitose & + & + & + & - \\
\hline Starch (amidon) & + & + & + & - \\
\hline Glycogen & + & + & + & - \\
\hline Xylitol & + & + & - & - \\
\hline Gentiobiose & + & + & $+/-$ & - \\
\hline Aerobic growth at $37^{\circ} \mathrm{C}$ & + & + & + & $+/-$ \\
\hline Catalase & $+/-$ & - & $+/-$ & + \\
\hline Oxidase & $+/-$ & $+/-$ & $+1-$ & - \\
\hline
\end{tabular}

for $6 \mathrm{~d}$ on LB or Columbia blood agar, the strains formed yellow or white-grey colonies of 1-2 mm diameter. Aerobic growth on LB agar was optimal at $\mathrm{pH} 7 \cdot 5$. Under these conditions, cells grew equally well at 30 and $37^{\circ} \mathrm{C}$. Phase-contrast microscopy of liquid cultures revealed non-motile, Gram-positive, predominantly short rods with rare longer and club-like forms $(0 \cdot 4-0 \cdot 7 \mu \mathrm{m}$ wide and 1.2-3.1 $\mu \mathrm{m}$ long). Electron microscopy showed the presence of stalk-like elements up to $300 \mathrm{~nm}$ long at the poles of some cells (Fig. 3).

\section{Metabolic properties}

The general metabolic properties of strains Se-3111 ${ }^{\mathrm{T}}$, Se-13111 and Se-1311A in comparison with those of their phylogenetic neighbour, B. cavernae, are pre- 


$\underline{\text { Similarity }(\%)} \longrightarrow$ Fragment size $(\mathrm{kb})$

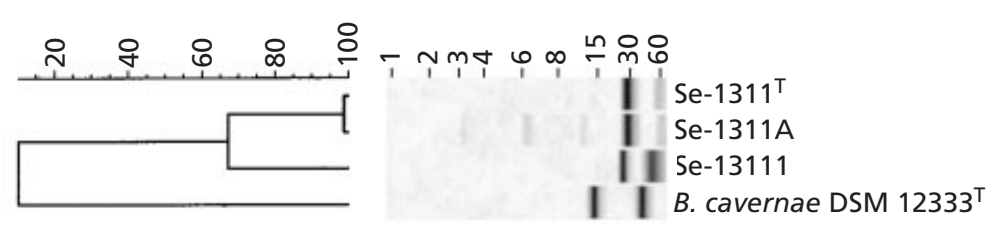

Fig. 4. Dendrogram showing similarity of the ribotype patterns of the novel strains and $B$. cavernae using the restriction enzyme Pvull. Cluster analysis was performed by UPGMA based on Pearson's correlation coefficient, using an optimization coefficient of $1 \cdot 2 \%$. sented in Table 2. Only those reactions in which the three isolates differ amongst themselves and/or from $B$. cavernae are shown. The isolates are characterized by their ability to grow under aerobic and anaerobic conditions. Acidification of growth medium occurred in the presence of a large range of sugars and carbohydrates, the range of which was more pronounced than that shown by B. cavernae. Gelatin and aesculin were not hydrolysed. Indole was not formed and urease was negative. API ZYM reactions were as follows: all strains including B. cavernae were positive for alkaline phosphatase, esterase $\left(\mathrm{C}_{4}\right)$, esterase lipase $\left(\mathrm{C}_{8}\right)$, leucine arylamidase, cystine arylamidase, acid phosphatase, naphthol AS-BI-phosphohydrolase, $\alpha$ galactosidase, $\beta$-galactosidase, $\alpha$-glucosidase, $N$ acetyl- $\beta$-glucosaminidase and $\alpha$-mannosidase; the reactions for chymotrypsin and $\beta$-glucuronidase were negative for all strains including $B$. cavernae. Acid was formed under aerobic conditions (according to API $50 \mathrm{CH}$ ) from L-arabinose, galactose, D-glucose, Dfructose, D-mannose, maltose, melibiose, sucrose, trehalose, D-raffinose, D-turanose and D-lyxose; in contrast to results given in the literature (Groth et al., 1999b), salicin, cellobiose and inulin gave no acid formation for $B$. cavernae. All strains including $B$. cavernae were negative for acid production from erythritol, L-xylose, adonitol, L-sorbose, rhamnose, dulcitol, inositol, mannitol, sorbitol, methyl $\alpha$-Dglucoside, $N$-acetylglucosamine, D-tagatose, D-fucose, L-fucose, D-arabitol, L-arabitol, gluconate, 2-ketogluconate and 5-ketogluconate.

\section{Anaerobic selenate reduction}

As determined by ETAAS analysis, strains Se-3111 ${ }^{\mathrm{T}}$, Se-13111 and Se-1311A formed insoluble, elemental selenium when grown anaerobically in medium containing selenate $\left(3.9 \times 10^{-6}-2.8 \times 10^{-5} \mathrm{~mol} \mathrm{l}^{-1}\right)$.

\section{Ribotyping}

Automated riboprinting is a useful application for the identification of isolates at the species level, as shown by Busse et al. (2000) and Fritze \& Pukall (2001). The three novel isolates Se-3111 ${ }^{\mathrm{T}}$, Se-13111, Se-1311A and their closest phylogenetic neighbour, B. cavernae, were ribotyped using the restriction enzyme PvuII. As shown in Fig. 4, similarity values between ribotype patterns of the novel isolates ranged from 65 to greater than $95 \%$, compared with less than $20 \%$ similarity to the ribotype pattern of $B$. cavernae. We therefore conclude that the novel isolates were genotypically very similar and represent a single species. The novel strains can easily be differentiated by ribotyping from their closest phylogenetic neighbour, B. cavernae.

\section{Taxonomic position of the novel isolates}

Neither the genotypic nor phenotypic characteristics of the novel isolates allow an affiliation to a currently described genus within the suborder Micrococcineae of the class Actinobacteria. Therefore, we propose to classify these strains in a new genus and species, for which the name Salana multivorans gen. nov., sp. nov. is proposed.

\section{Description of Salana gen. nov.}

Salana (Sa.la'na. N. L. fem. n. Salana she from the Saale, referring to the River Saale in Germany, the source of the bioreactor culture).

Cells form irregular rods and cocci, sometimes clublike forms. Gram-positive, facultatively anaerobic bacteria. A variety of organic electron donors may be utilized. The peptidoglycan is of the A4 $\beta$ type with an $\mathrm{L}$-Orn $\leftarrow \mathrm{L}$-Glu interpeptide bridge and an $\mathrm{L}$-Ser residue at position 1 of the peptide subunit. The polar lipids are phosphatidylglycerol, diphosphatidylglycerol and several unidentified phospholipids in minor amounts. The fatty acid pattern is of the iso- and anteisobranched and straight-chain saturated type. The major menaquinone is $\mathrm{MK}-8\left(\mathrm{H}_{4}\right)$. The $\mathrm{G}+\mathrm{C}$ content is 75 mol\%. Phylogenetically, the genus Salana belongs to the suborder Micrococcineae of the class Actinobacteria. The type species is Salana multivorans.

\section{Description of Salana multivorans sp. nov.}

Salana multivorans (mul'ti.vor.ans. L. adj. multus many, numerous; L. v. vorare to devour, swallow; N. L. part. adj. multivorans devouring many, referring to the utilization of numerous kinds of substrates).

Cells are Gram-positive, non-motile, rod-shaped to circular and sometimes club-like, 0.4-0.7 $\mu \mathrm{m}$ wide and $1 \cdot 2-3 \cdot 1 \mu \mathrm{m}$ long. Growth occurs under both aerobic and anaerobic conditions. Under aerobic conditions, optimal growth occurs at $\mathrm{pH} 7.5$ and 30 or $37^{\circ} \mathrm{C}$. Under anaerobic conditions, cells reduce selenate to 
elemental selenium. Some metabolic properties are described in the text and in Table 2. The peptidoglycan type, polar lipids, fatty acid pattern and major menaquinone are as described for the genus. The $\mathrm{G}+\mathrm{C}$ content is $75 \mathrm{~mol} \%$. Isolated from an anaerobic dechlorinating consortium enriched from river sediment.

The type strain is Se-3111 ${ }^{\mathrm{T}}$, which has been deposited in the DSMZ as DSM $13521^{\mathrm{T}}$ and in the NRRL culture collection as NRRL B-24118 ${ }^{\mathrm{T}}$.

\section{ACKNOWLEDGEMENTS}

The authors would like to thank Burkhard Selent (TUBerlin) for running the bioreactor and Hans G. Trüper for help with nomenclature. The work was supported by grants from the Deutsche Forschungsgemeinschaft (Sfb193/D6YE1 and SCHN 317/6-5 to U.B.G.) and by the Studienstiftung des Deutschen Volkes (F.v.W.).

\section{REFERENCES}

Busse, H.-J., Kainz, A., Tsitko, I. V. \& Salkinoja-Salonen, M. (2000). Riboprints as a tool for rapid preliminary identification of sphingomonads. Syst Appl Microbiol 23, 115-123.

Cashion, P., Holder-Franklin, M. A., McCully, J. \& Franklin, M. (1977). A rapid method for the base ratio determination of bacterial DNA. Anal Biochem 81, 461-466.

Collins, M. D. \& Jones, D. (1980). Lipids in the classification and identification of coryneform bacteria containing peptidoglycans based on 2,4-diaminobutyric acid. J Appl Bacteriol 48, 459-470.

De Soete, G. (1983). A least square algorithm for fitting additive trees to proximity data. Psychometrika 48, 621-626.

El Fantroussi, S., Naveau, H. \& Agathos, S. N. (1998). Anaerobic dechlorinating bacteria. Biotechnol Prog 14, 167-188.

Felsenstein, J. (1985). Confidence limits on phylogenies: an approach using the bootstrap. Evolution 39, 783-791.

Felsenstein, J. (1993). PHYLIP (phylogenetic inference package), version 3.5.1. Department of Genetics, University of Washington, Seattle, WA, USA.

Fritze, D. \& Pukall, R. (2001). Reclassification of bioindicator strains Bacillus subtilis DSM 675 and Bacillus subtilis DSM 2277 as Bacillus atrophaeus. Int J Syst Evol Microbiol 51, 35-37.

Groth, I., Schumann, P., Weiss, N., Martin, K. \& Rainey, F. A. (1996). Agrococcus jenensis gen. nov., sp. nov., a new genus of actinomycetes with diaminobutyric acid in the cell wall. Int $J$ Syst Bacteriol 46, 234-239.

Groth, I., Schumann, P., Rainey, F. A., Martin, K., Schuetze, B. \& Augsten, K. (1997a). Bogoriella caseilytica gen. nov., sp. nov., a new alkaliphilic actinomycete from a Soda Lake in Africa. Int $J$ Syst Bacteriol 47, 788-794.

Groth, I., Schumann, P., Rainey, F. A., Martin, K., Schuetze, B. \& Augsten, K. (1997b). Demetria terragena gen. nov., sp. nov., a new genus of actinomycetes isolated from compost soil. Int $J$ Syst Bacteriol 47, 1129-1133.

Groth, I., Schumann, P., Martin, K., Schuetze, B., Augsten, K., Kramer, I. \& Stackebrandt, E. (1999a). Ornithinicoccus hortensis gen. nov., sp. nov., a soil actinomycete which contains Lornithine. Int J Syst Bacteriol 49, 1717-1724.

Groth, I., Schumann, P., Schuetze, B., Augsten, K., Kramer, I. \& Stackebrandt, E. (1999b). Beutenbergia cavernae gen. nov., sp. nov., an L-lysine-containing actinomycete isolated from a cave. Int J Syst Bacteriol 49, 1733-1740.

Groth, I., Schumann, P., Weiss, N., Schuetze, B., Augsten, K. \& Stackebrandt, E. (2001). Ornithinimicrobium humiphilum gen. nov., sp. nov., a novel soil actinomycete with L-ornithine in the peptidoglycan. Int J Syst Evol Microbiol 51, 81-87.

Holliger, C., Gaspard, S., Glod, G., Heijman, C., Schuhmacher, W., Schwarzenbach, R. P. \& Vazquez, F. (1997). Contaminated environments in the subsurface and bioremediation: organic contaminants. FEMS Microbiol Rev 20, 517-523.

Jukes, T. H. \& Cantor, C. R. (1969). Evolution of protein molecules. In Mammalian Protein Metabolism, pp. 21-132. Edited by H. N. Munro. New York: Academic Press.

Ludwig, W. \& Strunk, O. (1997). ARB : a software environment for sequence data, version $2.5 \mathrm{~b}$. http://www.mikro.biologie.tumuenchen.de/pub/ARB/documentation/arb.ps

MacKenzie, S. L. (1987). Gas chromatographic analysis of amino acids as the $N$-heptafluorobutyryl isobutyl esters. $J$ Assoc Off Anal Chem 70, 151-160.

Macy, J. M., Michel, T. A. \& Kirsch, D. G. (1989). Selenate reduction by a Pseudomonas species: a new mode of anaerobic respiration. FEMS Microbiol Lett 52, 195-198.

Macy, J. M., Rech, S., Auling, G., Dorsch, M., Stackebrandt, E. \& Sly, L. I. (1993). Thauera selenatis gen. nov., sp. nov., a member of the beta subclass of Proteobacteria with a novel type of anaerobic respiration. Int J Syst Bacteriol 43, 135-142.

Mesbah, M., Premachandran, U. \& Whitman, W. B. (1989). Precise measurement of the $\mathrm{G}+\mathrm{C}$ content of deoxyribonucleic acid by high-performance liquid chromatography. Int $J$ Syst Bacteriol 39, $159-167$.

Minnlkin, D. E., Collins, M. D. \& Goodfellow, M. (1979). Fatty acid and polar lipid composition in the classification of Cellulomonas, Oerskovia and related taxa. J Appl Bacteriol 47, 87-95.

Nowak, J. (1994). Umsatz von Chlorbenzolen durch methanogene Mischkulturen aus Saalesediment in batch- und Reaktorversuchen. $\mathrm{PhD}$ thesis. Berichte zur Siedlungswasserwirtschaft 4, Technische Universität Berlin, Germany.

Saitou, N. \& Nei, M. (1987). The neighbor-joining method: a new method for reconstructing phylogenetic trees. Mol Biol Evol 4, 406-425.

Schleifer, K. H. (1985). Analysis of the chemical composition and primary structure of murein. Methods Microbiol 18, 123-156.

Schleifer, K. H. \& Kandler, O. (1972). Peptidoglycan types of bacterial cell walls and their taxonomic implications. Bacteriol Rev 36, 407-477.

Schlötelburg, C., von Wintzingerode, F., Hauck, R., Hegemann, W. \& Göbel, U. B. (2000). Bacteria of an anaerobic 1,2dichloropropane-dechlorinating mixed culture are phylogenetically related to those of other anaerobic dechlorinating consortia. Int J Syst Evol Microbiol 50, 1505-1511.

Schumann, P., Prauser, H., Rainey, F. A., Stackebrandt, E. \& Hirsch, P. (1997). Friedmanniella antarctica gen. nov., sp. nov., an LL-diaminopimelic acid-containing actinomycete from Antarctic sandstone. Int J Syst Bacteriol 47, 278-283.

Selent, B. (1999). Kombinierter anaerober und aerober Abbau von Chlorbenzolen mit immobilisierten Mikroorganismen. $\mathrm{PhD}$ thesis. Berichte zur Siedlungswasserwirtschaft 11, Technische Universität Berlin, Germany.

Shelton, D. R. \& Tiedje, J. M. (1984). General method for determining anaerobic biodegradation potential. Appl Environ Microbiol 47, 850-857. 
Stackebrandt, E., Rainey, F. A. \& Ward-Rainey, N. (1997). Proposal for a new hierarchic classification system, Actinobacteria classis nov. Int J Syst Bacteriol 47, 479-491.

von Wintzingerode, F. (1999). Untersuchungen zur mikrobiellen Diversität einer anaeroben, Trichlorbenzol-dechlorierenden Mischkultur. PhD thesis. Humboldt Universität zu Berlin, Germany. http://dochost.rz.hu-berlin.de/dissertationen/ biologie/wintzingerode-friedrich-von/ von Wintzingerode, F., Selent, B., Hegemann, W. \& Göbel, U. B. (1999). Phylogenetic analysis of an anaerobic, trichlorobenzenetransforming microbial consortium. Appl Environ Microbiol 65, 283-286.

von Wintzingerode, F., Landt, O., Ehrlich, A. \& Göbel, U. B. (2000). Peptide nucleic acid-mediated PCR clamping as a useful supplement in the determination of microbial diversity. Appl Environ Microbiol 66, 549-557. 